\title{
DETECTION OF ANTIFUNGAL COMPOUNDS IN ARABIDOPSIS THALIANA AND BRASSICA OLERACEA BY THIN LAYER CHROMATOGRAPHY
}

\author{
K.P. Chong ${ }^{*}$ \\ School of Science and Technology, Universiti Malaysia Sabah, \\ 88999, Kota Kinabalu, Sabah, Malaysia \\ J.W. Mansfield, M.H. Bennett and J.F. Rossiter \\ Division of Biology, Imperial College, Wye, Ashford, Kent, \\ TN25 5AH, United Kingdom
}

Received 29 November 2005

\begin{abstract}
Thin Layer Chromatography (TLC) was applied to detect antifungal compounds both in Arabidopsis thaliana and Brassica oleracea after elicited by various biotic and abiotic elicitors. From TLC bioassays the only strong zone of inhibition detected after challenged by Pseudomonas syringae pv. maculicola was from Arabidopsis tissue and later confirmed by spectrophotometry as camalexin but no corresponding phytoalexin was found in broccoli leaf.
\end{abstract}

Keywords: Thin Layer Chromatography, phytoalexin, camalexin, brassilexin, Pseudomonas syringae pv. maculicola

\section{INTRODUCTION}

Plants are constantly live under uncertainty environment with the mercy of wind, rain, UV radiation, herbivores and pathogens attack. To impede to this different uncertainties they need special defence mechanisms [12]. Some plants may produce some antimicrobial compounds after pathogen attack such as secondary metabolites being known as phytoalexins. These compounds have demonstrated a striking activity in vitro against potential pathogens [10].

Phytoalexins have been defined as low molecular weight antimicrobial compounds that are both synthesized and accumulate in plants after exposure to microorganism [13]. Most research on resistance mechanisms has shown that the plant uses defences that are activated after infection to stop pathogen development [4]. Phytoalexins have been characterized from 31 plant families [7]. To some extent the chemical class of compound is related to the plant family. Camalexin (3thiazol-2 methyl-indole) an indolic secondary metabolite [11] is a type of phytoalexin that is involved in plant-pathogen interaction in Arabidopsis thaliana [21]. This phytoalexin is induced under pathogen attack or by abiotic elicitors that generate reactive oxygen species $[21,15,17]$

${ }^{*}$ Corresponding author e-mail: khimphin@hotmail.com 
or cell death [9]. Many observations support the proposal that camalexin plays a role in the Arabidopsis defence system after challenged by plant pathogens [8, 6, 20, 5, 3]. In other hand, the first phytoalexin discovered in Brassica was brassilexin, a natural origin isothiazole derivative from Brassica juncea (brown mustard) [11]. Another three new phytoalexins from Brassica napus spp. rapifera (rutabaga) are isalexin, brassicanate A, and rutalexin, and another five known phytoalexins are brassinin, 1-methoxybrassinin, spirobrassinin, brassicanal A, and brassilexin [14]. These phytoalexins have shown to be good inhibitory compounds to pathogens attack [14, 18]. The resistance of Brassica plants including Arabidopsis have been widely investigated [1] but most studies have been concentrated on genetics of resistance rather than accumulation of secondary metabolites or antimicrobial compounds. In consequence there is little knowledge of phytoalexins in broccoli. In this study, we looked for the antifungal compounds in both Arabidopsis and Brassica oleracea (broccoli) using Thin Layer Chromatography (TLC) after challenged by several biotic and abiotic elicitors.

\section{EXPERIMENTAL}

\subsection{Plants}

Broccoli plants were grown under greenhouse conditions and provided by technical staff of Imperial College.

Arabidopsis thaliana ecotype Col-5 seeds were sown with three parts of Levington commercial peat compost and one part vermiculite. Ingredients were mixed and distributed into pots. After sowing, the pots were placed in tray of water to moisturise the mixture. Seed trays were then covered with aluminum foil for seed to vernalise and incubate at $4^{\circ} \mathrm{C}$ for $4-5$ days. Trays were then transferred to a growth room with 10 hours photo period, a light intensity of $40 \mathrm{~W} / \mathrm{m}^{2}$ and a temperature of $20-21^{\circ} \mathrm{C}$. After cotyledon development, seedlings were transplanted to individual pots $\left(25 \mathrm{~cm}^{2}\right)$. Under such conditions the plants developed large extensive rosette leaves suitable for inoculation after 6 - 8 weeks.

\subsection{Botrytis cinerea}

Botrytis cinerea isolated originally from tomato was obtained from a stock culture from Imperial College Wye Campus and maintained on Petri dish plates of Potato Dextrose Agar (PDA). The medium was produced by suspending $3.9 \mathrm{~g}$ of PDA in $1000 \mathrm{ml}$ sterilize double distilled water (SDDW) and autoclaved to sterilize at $121^{\circ} \mathrm{C}$ for 15 minutes. Suspensions of conidia were prepared by flooding sporulating cultures (7 - 10 days old) with SDDW. The resultant suspension was filtered and washed twice. Conidia were pelleted by centrifugation at $3 \mathrm{~K} \mathrm{rpm}$ for 3 minutes using a Denley BS400 centrifuge. The concentration of spores used was adjusted to $2.5 \times 10^{5} \mathrm{ml}^{-1}$ using a haemocytometer. The suspension was used with $1 / 64$ strength of potato dextrose broth (PDB) was prepared by adding $24 \mathrm{~g}$ of PDB into $1000 \mathrm{ml}$ of SDDW and autoclaved at $121^{\circ} \mathrm{C}$ for 15 minutes.

\subsection{Bacterial cultures and inoculation}

Bacteria (Pseudomonas syringae pv. phaseolicola Race 6 (R6) and Race 7 (R7) and P.s pv. maculicola were obtained from a stock culture from Imperial College Wye campus and maintained on Petri dish plates of Kings B medium. Suspensions of bacteria were prepared by transferring a small portion of culture from the stock to $10 \mathrm{ml}$ Luria Bertani broth with $50 \mu \mathrm{g} / \mathrm{ml}$ rifampicin. The suspensions were incubated in a controlled environment shaker (New Brunswick Scientific, U.S) overnight and were spun down the next day (3 K rpm). $\mathrm{MgCl}_{2}(10$ 
$\mathrm{mM}$ ) used to resuspend the bacterial pellet, and centrifugation repeated to wash cells before final adjustment to the required optical density (OD). Leaves were wounded followed by inoculation with a $1 \mathrm{ml}$ BD Plastikpak blunt syringe.

\subsection{Spectrophotometry}

A Cecil Series 2 ultraviolet spectrophotometer was used to adjust OD of bacteria in $10 \mathrm{mM}$ of $\mathrm{MgCl}_{2}$. The wavelength was set to $600 \mathrm{~nm}$. Fisherbrand FB55147 Polystyrene Semi-micro Cuvets were used with this spectrophotometer.

A Philips SP 8 - $100 \mathrm{UV} /$ Vis spectrophotometer was used to confirm the presence of camalexin. Bandwidth was set to $0.5 \mathrm{~nm}$ with wavelength speed of $5 \mathrm{~nm}$ per second. Absorbance was set to 1 with chart speed 2 second per $\mathrm{cm}$. Wavelength was turned to $400 \mathrm{~nm}$. Wavelength drive, UV lamp and recorder were turned on to record the absorbance. Hellma Precision Cells of Quartz glass (Suprasil) with a light path of $10 \mathrm{~mm}$ were used with the spectrophotometer.

\subsection{Thin Layer Chromatography bioassays}

Treated tissues from stem and leaves of broccoli and leaves of Arabidopsis were weighed and soaked overnight in ethyl acetate: ethanol $(50: 50, \mathrm{v} / \mathrm{v})$. The tissue extracts were then transferred to flasks and evaporated to dryness. Leaf tissues inoculated with B. cinerea were soaked in ethyl acetate: ethanol $(50: 50, \mathrm{v} / \mathrm{v})$ and after collection of the extract soaked again in methanol overnight to test if ethyl acetate: ethanol $(50: 50, \mathrm{v} / \mathrm{v})$ recovered all inhibitors. After the first evaporation, the extracts were resuspended in ethanol and again evaporated. In the final extracts, ethanol was added to give $1 \mathrm{ml}$ of ethanol per gram of leaf tissue fresh weight for all extracts except $1 \mathrm{ml}$ per $10 \mathrm{~g}$ of broccoli stem. Extracts $(0.1$ or $0.2 \mathrm{ml})$ were applied to 1 or $2 \mathrm{~cm}$ origins on TLC plates (Merck Kiesel 60 F254 silica gel). Plates were developed in chloroform: methanol $(9: 1, \mathrm{v} / \mathrm{v})$ or $(20: 1, \mathrm{v} / \mathrm{v})$. When the solvent reached $16 \mathrm{~cm}$ from the starting point, the plates were taken out and examined under UV light $366 \mathrm{~nm}$ wavelength. The plates were then sprayed with 7 - 10 days old spores of Cladosporium herbarum suspended in PDB suspension and incubated in a moist chamber for 2 days at $20^{\circ} \mathrm{C}-22^{\circ} \mathrm{C}$. Dense spore suspensions were prepared as described for $B$. cinerea except that one or two droplets of Tween 20 were added to each culture of $C$. herbarum.

\section{RESULTS}

\subsection{Bioassays to detect antifungal compounds using TLC bioassays}

From published papers various types of elicitation were expected to cause phytoalexin accumulation in Arabidopsis and also broccoli. As a preliminary approach to the detection of inhibitors that could be involved in restriction to pathogen attack, various treatments were assessed using TLC plate bioassays to search for antifungal compounds.

A summary of different challenges and zones of inhibition detected is given in Table 1. Full details of the analysis of tissues are presented in the following sub-sections.

\subsubsection{Challenge with $\mathrm{CuSO}_{4}$}

Broccoli stems were cut into discs sized $1.0-1.5 \mathrm{~cm}$ in diameter and $0.5 \mathrm{~cm}$ thick, weighed elicited by soaking into $5 \%$ of $\mathrm{CuSO}_{4}$ and SDDW (as control) for 30 minutes. After washing with SDDW they were incubated in sandwich boxes under high humidity for two days. 
Arabidopsis leaves were wounded with a razor blade and treated with $\mathrm{CuSO}_{4}$ in the same way as broccoli stems. On chromatograms, although no fluorescent bands were observed in extracts from broccoli stems under UV, strong inhibition zones appeared $11 \mathrm{~cm}$ from the origin using both 0.2 and $0.1 \mathrm{ml}$ of extracts from $\mathrm{CuSO}_{4}$ elicited stem (Fig. 1). Weak inhibition zones were also present in the controls $9 \mathrm{~cm}$ from origin both in 0.2 and $0.1 \mathrm{ml}$ (Fig. 1). By contrast, no inhibition zones were present in both $\mathrm{CuSO}_{4}$ elicited and control leaves of Arabidopsis (Fig. 2).

Table 1: Different types of challenge to tissues of Arabidopsis and broccoli and detection of zones of inhibition by TLC bioassays

\begin{tabular}{|c|c|c|c|}
\hline Plant & Tissue & Challenge & Detection of zone of inhibition \\
\hline \multirow[t]{6}{*}{ Arabidopsis } & Leaf & $\mathrm{CuSO}_{4}$ & - \\
\hline & & P. s. pv. phaseolicola Race & - \\
\hline & & P. s. pv. phaseolicola Race 7 & \\
\hline & & P. s. pv. maculicola & \\
\hline & & Hypersensitive (HR) tissues & Strong inhibition ${ }^{\mathrm{a}}$ \\
\hline & & B. cinerea (Limited lesions) & Weak inhibition $^{-}$ \\
\hline \multirow[t]{4}{*}{ Broccoli } & Leaf & P. s. pv. phaseolicola Race 6 & - \\
\hline & & P.s. pv. phaseolicola Race 7 & \\
\hline & & B. cinerea (Limited lesions) & \\
\hline & Stem & $\mathrm{CuSO}_{4}$ & Strong inhibition \\
\hline
\end{tabular}

${ }^{\mathrm{a}}$ Zones associated with camalexin

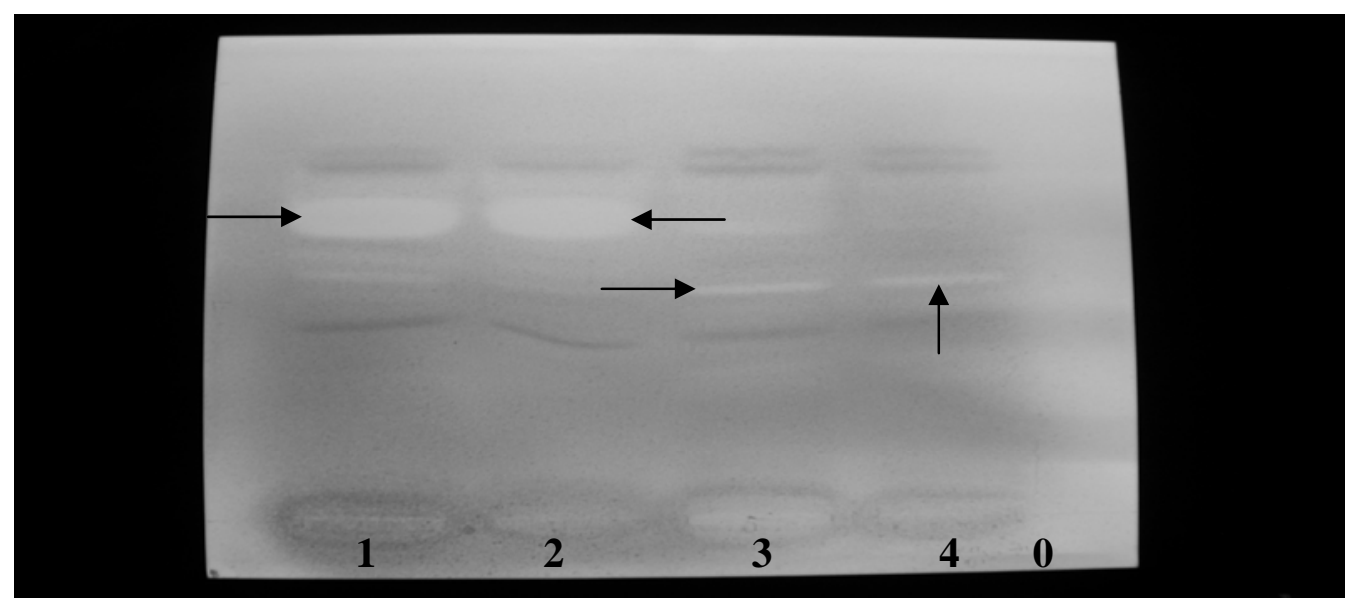

Fig. 1: Detection of inhibitors by TLC bioassay of extracts from broccoli stems treated with $\mathrm{CuSO}_{4}$. All extracts applied over $2 \mathrm{~cm}$ length on origin (0); (1) $2.0 \mathrm{~g}$ of treated tissues; (2) $1.0 \mathrm{~g}$ of treated tissues; (3) $2.0 \mathrm{~g}$ of untreated tissues as control; (4) $1.0 \mathrm{~g}$ of untreated tissues for control. Inhibition bands arrowed. Developed in: chloroform: methanol $(9: 1, v / v)$ 


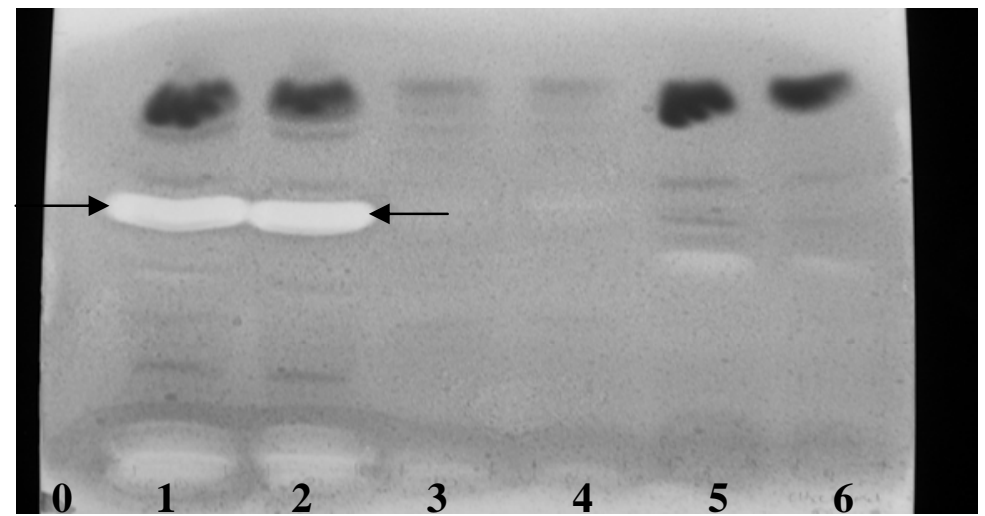

Fig. 2: Detection of inhibitors by TLC bioassay of extracts from P. s. pv. maculicola infected and $\mathrm{CuSO}_{4}$ elicited Arabidopsis leaves. All extracts were applied to $2 \mathrm{~cm}$ length on origin (0); (1) $0.2 \mathrm{~g}$ of tissues infected with P. s. pv. maculicola; (2) $0.1 \mathrm{~g}$ of tissues infected with P. $\mathrm{s}$. pv. maculicola; (3) $0.2 \mathrm{~g}$ of tissues elicited by $\mathrm{CuSO}_{4}$; (4) $0.1 \mathrm{~g}$ of tissues elicited by $\mathrm{CuSO}_{4}$. (5) $0.2 \mathrm{~g}$ of untreated tissues as control; $\quad$ (6) $0.1 \mathrm{~g}$ of untreated tissues as control. Inhibitory bands arrowed. Developed in: chloroform: methanol (9:1, v/v). Note the lower $R_{f}$ of the zones of inhibition than in Fig. 1 lanes 1 and 2.

\subsubsection{Challenge with bacteria}

Broccoli and Arabidopsis leaves were wounded with a razor blade and inoculated with P. s. pv. phaseolicola R6 and R7. In broccoli these inocula caused hypersensitive (HR) development with rapid lesion production within 2 days. In Arabidopsis, however, lesion development occurred at very few sites and was mostly apparent as yellowing of tissue rather than HR collapse. HR tissues of broccoli, yellowing tissues of Arabidopsis and healthy fresh tissues (as control) were collected after three days (for P. s. pv. phaseolicola R6) and five days (for R6 and R7). P. s. pv. maculicola infected Arabidopsis leaves (HR tissues) were also collected from other laboratory members for this bioassay. Although extracts of Arabidopsis tissue infected with P. s. pv. phaseolicola R6 and R7 produced fluorescing bands under the UV, no zones of inhibition were found on the TLC plate bioassays (Figs. 3 \& 4). By contrast P. s. pv. maculicola infected leaves of Arabidopsis (HR tissues) produced strong inhibition zones at the same distance from the origin where light purple fluorescence appeared under UV $365 \mathrm{~nm}$ with $\mathrm{R}_{\mathrm{f}}$ value 0.6 (Fig. 2). No bands of fluorescence or zones of inhibition were found in extracts of broccoli.

\subsubsection{Challenge with B. cinerea}

Broccoli and Arabidopsis leaves were cut from six weeks old plants and inoculated with $2.5 \times$ $10^{5}$ spores of $B$. cinerea in $1 / 64$ strength PDB. B. cinerea will produce limited and non spreading lesions both in broccoli and Arabidopsis with this strength of PDB [2]. Each $20 \mu 1$ inoculum was inoculated on the lower leaves surface and leaves were incubated in sandwich boxes under high humidity. Limited lesions and fresh tissues (as control) were collected after four days. TLC extracts of Arabidopsis with limited lesions revealed a zone of weak inhibition but this was not clearly visible in samples from broccoli. Inoculum droplets were also collected and extracted with diethyl ether to recover any diffusible phytoalexins. Twice the volume of diethyl ether was added to the suspension and the two phases were mixed well with a pipette for extraction. The upper ether phase was transferred to a flask for evaporation. The extraction was repeated once. The residual soluble phase was used for bioassays. The ether extracts did not produce zones of inhibition (Fig. 5). 


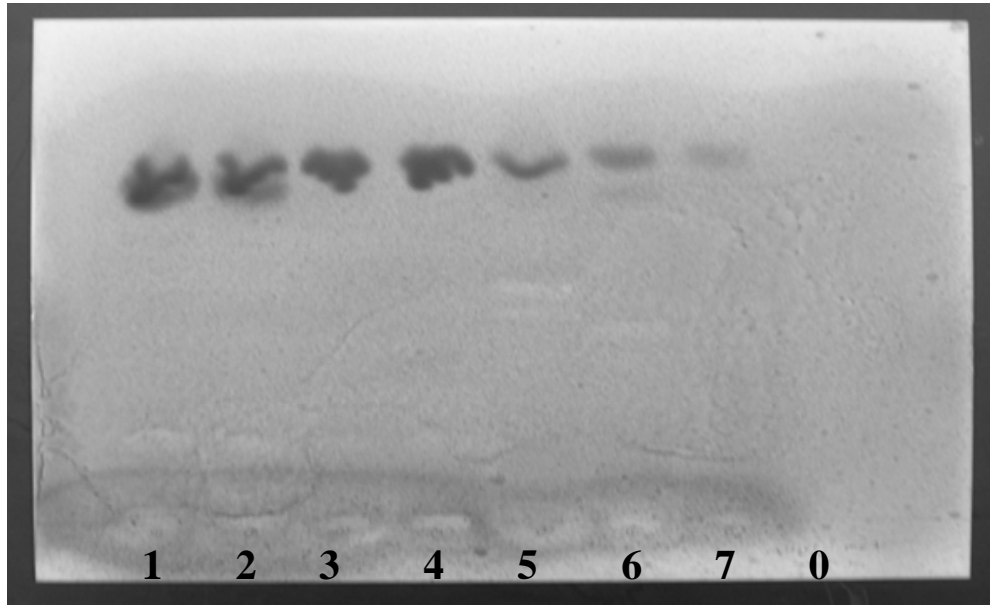

Fig. 3: Detection of inhibitors by TLC bioassay of extract from P. s. pv. phaseolicola infected broccoli leaves. All applied as $0.2 \mathrm{~g}$ of infected tissues per $1 \mathrm{~cm}$ length on origin (0); (1) Infected tissues by 0.5 OD of P. s. pv. phaseolicola R6 (tissues collected after 3 days infected); (2) Infected tissues by 0.4 OD of P.s. pv. phaseolicola R6 (tissues collected after 3 days infected); (3) Uninfected tissues as control; (4) Tissues inoculated with water; (5) Unhealthy tissues; (6) Infected tissues by $0.4 \mathrm{OD}$ of P. s. pv. phaseolicola R6 (tissues collected after 5 days infected); (7) Infected tissues by 0.4 OD of P. s. pv. phaseolicola R7 (tissues collected after 5 days infected). Developed in: chloroform: methanol (20:1, v/v)

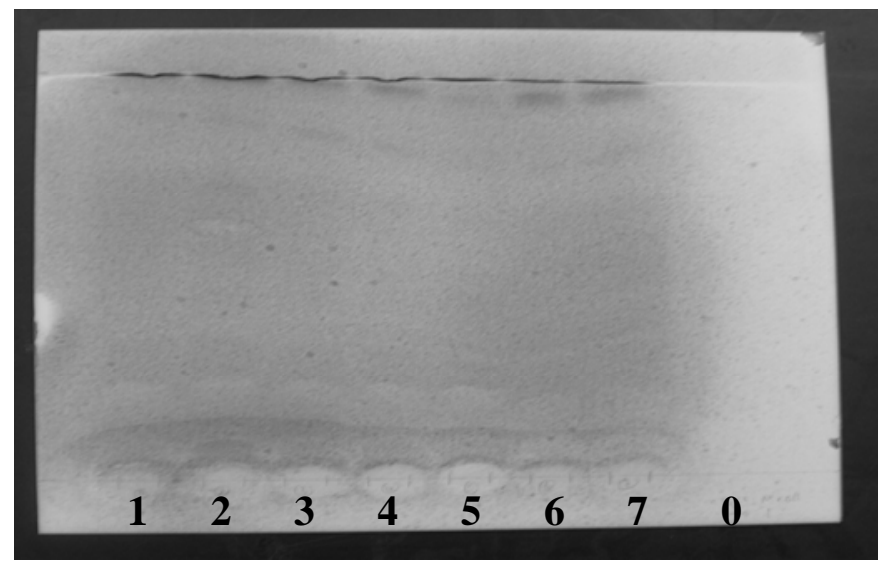

Fig. 4: Detection of inhibition by TLC bioassay of extract from Arabidopsis leaves challenged with different concentrations and races of $P$. S. pv. phaseolicola. All applied with $0.2 \mathrm{~g}$ of tissues per $2 \mathrm{~cm}$ length on origin (0); (1) $0.5 \mathrm{OD}$ of P. s. pv. phaseolicola R6 (collected after 3 days infected); (2) 0.4 OD of P.s. pv. phaseolicola R6 (collected after 3 days infected); (3) Uninfected tissues as control; (4) Tissues inoculated with water (collected after 3 days inoculated); (5) Tissues inoculated with water (collected after 5 days inoculated); (6) 0.4 OD of P. s. pv. phaseolicola R6 (collected after 5 days infected); (7) 0.4 OD of P. s. pv. phaseolicola R7 (collected after 5 days infected). Developed in: chloroform: methanol $(20: 1, v / v)$. Note the absence of clear zone of inhibition from extracts of tissues without HR symptoms 


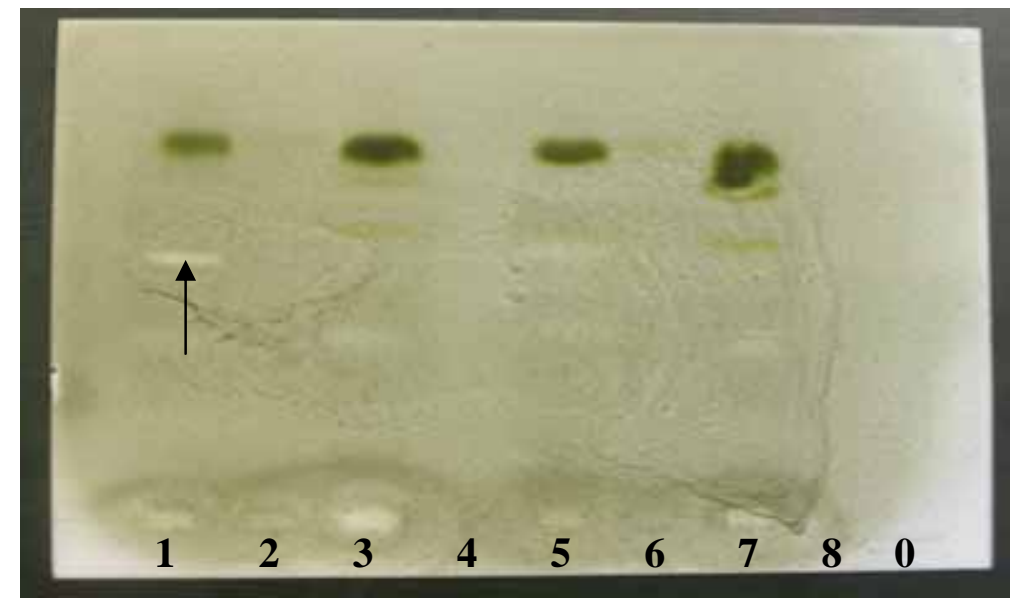

Fig. 5: $\quad$ Detection of inhibitors by TLC bioassay of extract from Arabidopsis and broccoli leaves challenged by B. cinerea. All extracts applied as $0.2 \mathrm{~g}$ of tissues per $2 \mathrm{~cm}$ length on origin (0); Bands (1)-(4): Arabidopsis and bands (5)-(8): Broccoli; (1) \& (5): Limited lesions produced by B. cinerea extracted with ethyl acetate: ethanol (50:50, v/v); (2) \& (6): Limited lesions produced by B. cinerea recovered with methanol after first extraction with ethyl acetate: ethanol (50:50, v/v); (3) \& (7): Uninfected tissues extracted with ethyl acetate: ethanol (50:50, v/v) as control; (4) \& (8): Inoculum droplets extracted with diethyl ether. Inhibition band arrowed. Developed in: chloroform: methanol $(9: 1, v / v)$

As a summary, the only strong zone of inhibition detected after antimicrobial challenge was from Arabidopsis tissue. The fluorescence of the band and its $R_{f}$ in chloroform: methanol (9:1 $\mathrm{v} / \mathrm{v})$ suggested that the phytoalexin was camalexin. Perhaps surprisingly no inhibitor corresponding to brassilexin was found in broccoli.

\section{DISCUSSION}

TLC bioassays were used to confirm the presence of phytoalexins in tissues. TLC is a rapid method which allows separation of small amounts of compounds. Depending on the absorbent used both polar and non-polar compounds can be resolved. Here we used silica gel to separate the relatively non-polar phytoalexin-like compounds. TLC bioassays have been widely used to study phytoalexins in different types of activity in Brassica. For example, it has been used to verify the presence of camalexin in Arabis lyrata after inoculation with P.s. pv. maculicola [22].

From the TLC bioassays, the only strong zone of inhibition detected after microbial challenge was from Arabidopsis tissue. The fluorescence of the band and its $\mathrm{R}_{\mathrm{f}}$ in chloroform: methanol $(9: 1 \mathrm{v} / \mathrm{v})$ suggested that the phytoalexin was camalexin [22] and this was later confirmed by UV spectrophotometry. Camalexin has a characteristic spectrum with $\lambda$ max at 318 and $275 \mathrm{~nm}$ [19]. Perhaps surprisingly no inhibitor corresponding to brassilexin was found in broccoli leaves. The zones of inhibition found after $\mathrm{CuSO}_{4}$ treatment of broccoli stems were not further characterized. Compared with $\mathrm{AgNO}_{3}, \mathrm{CuSO}_{4}$ was not a good elicitor of phytoalexin biosynthesis. Further investigation need to be done to verify the zone of inhibition found after $\mathrm{CuSO}_{4}$ treatment of broccoli stem. More research are needed to clarify the mechanism of resistance in broccoli against $B$. cinerea in low concentration of nutrient if resistance not caused by brassilexin 


\section{ACKNOWLEDMENTS}

The authors are very grateful for the scholarship given to Chong Khim Phin under Academic Staff Training Scheme of Universiti Malaysia Sabah.

\section{REFERENCES}

1. Bennett, R.N. and Wallsgrove, R.M. (1994), Secondary metabolites in plant defence mechanisms, New Phytologist, vol. 127, pp. 617-633.

2. Chong, K.P. (2005), Role of phytoalexin in Arabidopsis thaliana and Brassica oleracea against Botrytis cinerea, MRes thesis. Imperial College, University of London.

3. Denby, K.J., Kumar, P. and Kliebenstein, D.J. (2004), Identification of Botrytis cinerea susceptibility loci in Arabidopsis thaliana, The Plant Journal, vol. 38, pp. 473-486.

4. Dixon, R.A. and Harrison, M.J. (1990), Activation, structure and organization of genes involved in microbial defense in plants, Advance Genetics, vol. 28, pp. 165-234.

5. Ferrari, S., Plotnikova, J.M., De Lorenzo, G., and Ausubel, F.M. (2003), Arabidopsis local resistance to Botrytis cinerea involves salicylic acid and camalexin requires EDS4 and PAD2, but not SID2, EDS5 or PAD4, Plant Journal, vol. 35, pp. 193-205.

6. Govrin, E.M. and Levine, A. (2002), Infection of Arabidopsis with a necrotrophic pathogen Botrytis cinerea, elicits various defense responses but does not induce systemic acquires resistance (SAR), Plant Molecular Biology, vol. 48, pp. 267-276.

7. Grayer, R.J. and Harborne, J.B. (1994), A survey of antifungal compounds from plants,1982-1993, Phytochemistry, vol. 37, pp. 19-42.

8. Kagan, I. and Hammerschmidt, R. (2002), Arabidopsis ecotype variability in camalexin production and reaction to infection by Alternaria brassicicola, Journal of Chemistry Ecology, vol. 28, pp. 2121-2140.

9. Kliebenstein, D.J. (2004), Secondary metabolites and plant/environment interactions: A view through Arabidopsis thaliana tinged glasses, Plant, Cell and Environment, vol. 27, pp. 675-684.

10. Mansfield, J.W. (2000), Antimicrobial compounds and resistance. In: Slusarenko, A. Fraser, R.S.S. and Van Loon, L.C. (Eds.) (2000), Mechanism of Resistance to Plant Diseases, Netherlands, Kluwer Academic Publishers.

11. Miedzybrodzki, R. (2003), Biological activity of the isothiazole derivatives, Postepy Hig Med Dosw, vol. 57, pp. 617-630.

12. Maor, R. and Shirasu, K. (2005), The arms race continues: battle strategies between plants and fungal pathogens, Current Opinion in Microbiology, vol. 8, pp. 399-404.

13. Paxton, J. (1981), Phytoalexins - a working redefinition, Journal of phytopathology, vol. 101, pp. 106-109.

14. Pedras, M.S.C., Montaut, S., and Suchy, M. (2004), Phytoalexins from the Crucifer Rutabaga: Structures, Syntheses, Biosyntheses, and Antifungal Activity, Journal of Organic Chemistry, vol. 69, pp. 4471-4476.

15. Reuber, T.L., Plotnikova, J.M., Dewdney, J., Rogers, E.E., Wood, W., and Ausubel, F.M. (1998), Correlation of defense gene induction with powdery mildew susceptibility in Arabidopsis enhanced disease susceptibility mutants, Plant Journal, vol. 16, pp. 473-487. 
16. Rhodes, D. (2003), Secondary products derived from aromatic Amino acids [ONLINE] Available from: http://www.hort.purdue.edu/rhodcv/hort640c/secprod/se00001.html [Accessed 26 June 2005].

17. Roetschi, A., Si-Ammour, A., Belbahri, L., Mauch, F., and Mauch-Mani, B. (2001), Characterization of an Arabidopsis-phytopthora pathosystem: Resistance requires a functional $P A D 2$ gene and is independent of salicyclic acid, ethylene and Jasmonic acid signaling, Plant Journal, vol. 28, pp. 293-305.

18. Rouxel, T., Kollmann, A., Boulidard, L., and Mithen, R. (1991), Abiotic elicitation of indole phytoalexins and resistance to Leptosphaeria maculans within Brassiceae, Planta, vol. 184, pp. 271-278.

19. Soylu, S. (1998), Analysis of the responses of Arabidopsis thaliana to infection by Albugo candida and pathovars of Pseudomonas syringae, $\mathrm{PhD}$ thesis. Wye College, University of London.

20. Thomma, B.P., Nelissen, I., Eggermont, K., and Broekaert, W.F. (1999), Deficiency in phytoalexin production causes enhanced susceptibility of Arabidopsis thaliana to the fungus Alternaria brassicicola, Plant Journal, vol. 19, pp. 163-171.

21. Tsuji, J., Jackson, E.P., Gage, D.A., Hammerschmidt, R., and Somerville, S.C. (1992), Phytoalexin accumulation in Arabidopsis thaliana during the hypersensitive reaction to Pseudomonas syringae pv. syringae, Plant Physiology, vol. 98, pp.1304-1309.

22. Zook, M., Leege, L., Jacobson, D., and Hamerschmidt, R. (1998), Camalexin accumulation in Arabis lyrata, Phytochemistry, vol. 49, pp. 2287-2289. 